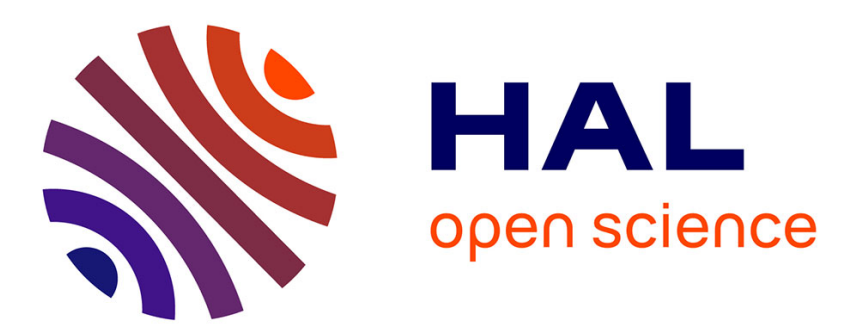

\title{
Cobalt(II) orthophosphate octahydrate
}

A Riou, Yannick Cudennec, Y Gerault

\section{To cite this version:}

A Riou, Yannick Cudennec, Y Gerault. Cobalt(II) orthophosphate octahydrate. Acta Crystallographica Section C: Crystal Structure Communications [1968-2013], 1989, 45, pp.1412 - 1413. 10.1107/s0108270189003616 . hal-03194811

\section{HAL Id: hal-03194811 \\ https://hal.science/hal-03194811}

Submitted on 9 Apr 2021

HAL is a multi-disciplinary open access archive for the deposit and dissemination of scientific research documents, whether they are published or not. The documents may come from teaching and research institutions in France or abroad, or from public or private research centers.
L'archive ouverte pluridisciplinaire HAL, est destinée au dépôt et à la diffusion de documents scientifiques de niveau recherche, publiés ou non, émanant des établissements d'enseignement et de recherche français ou étrangers, des laboratoires publics ou privés. 
Acta Cryst. (1989). C45, 1412-1413

https://doi.org/10.1107/S0108270189003616

\title{
Cobalt(II) Orthophosphate Octahydrate
}

\author{
By A. Riou, Y. Cudennec, and Y. Gerault \\ Laboratoire de Chimie des Matériaux Inorganiques et de Cristallographie, Institut National des Sciences Appliquées, \\ 20 avenue des Buttes de Coesmes, 35043 Rennes CEDEX, France
}

(Received 8 February 1989; accepted 15 March 1989)

\begin{abstract}
Co}_{3}\left(\mathrm{PO}_{4}\right)_{2} \cdot 8 \mathrm{H}_{2} \mathrm{O}, \mathrm{M}_{\mathrm{r}}=510.86$, monoclinic, $C 2 / m, a=10.021(3), b=13.331(3), c=$ 4.673 (2) $\AA, \beta=104.90(6)^{\circ}, V=603.3(0.8) \AA^{3}, D_{x}=2.812(4), D_{m}=2.78$ (2) Mg.m ${ }^{-3}, Z=2$, Mo $\mathrm{K} \alpha, \lambda=0.71073 \AA, \mu=4.425 \mathrm{~mm}^{-1}, F(000)=510$, room temperature, $R=0.018$ for 778 observed reflections. The structure is isotypic with vivianite: $\mathrm{Fe}_{3}\left(\mathrm{PO}_{4}\right)_{2} .8 \mathrm{H}_{2} \mathrm{O}$.
\end{abstract}

Experimental. Crystals of $\mathrm{Co}_{3}\left(\mathrm{PO}_{4}\right)_{2} .8 \mathrm{H}_{2} \mathrm{O}$ were obtained from a mixture of cobalt carbonate, phosphoric acid and water. After elimination of carbon dioxide, the reacting system belongs to the ternary system $\mathrm{CoO}, \mathrm{P}_{2} \mathrm{O}_{5}, \mathrm{H}_{2} \mathrm{O}$. A system composed of $8 \% \mathrm{CoO}, 10 \% \mathrm{P}_{2} \mathrm{O}_{5}, 82 \% \mathrm{H}_{2} \mathrm{O}$ (in weight) was slowly dehydrated at room temperature for several months. Pink rectangular plate-like crystals appeared on the edge of the reactor bottle. A suitable crystal $(0.18 \times 0.16 \times 0.05 \mathrm{~mm})$ was mounted on an Enraf-Nonius CAD-4 diffractometer using Mo $K \alpha$ radiation. Density measured by flotation. The unit-cell constants were determined and refined on the basis of 25 carefully centred reflections in the angular range $2<2 \theta<30^{\circ}$. Data were collected in the $\omega-2 \theta$ scan mode with $\omega$-scan width $(2.00+0.50 \operatorname{tg} \theta)^{\circ}$ and slit amplitude $(1.00+0.35 \operatorname{tg} \theta) \mathrm{mm}$. A total of 1022 reflections were measured. The $h, k, l$ range was $0 \leq h \leq 13,0 \leq k \leq 18,-6 \leq 1 \leq 6\left(2 \theta<56^{\circ}\right)$. A periodic check of three standard reflections showed no significant intensity variation. The internal consistency index $R_{\text {int }}$, was 0.016 . Reflections were merged to a unique set of 890 . According to I $>\sigma(\mathrm{I}), 778$ reflections were regarded as observed. Data were corrected for Lorentz and polarization effects and absorption corrections were applied. The structural determination was carried out on a PDP 11/60 computer using the SDP package (Frenz, 1978). Scattering factors were from Cromer \& Waber (1965). The structure was determined on the basis of isomorphism with $\mathrm{Mg}_{3}\left(\mathrm{PO}_{4}\right)_{2} .8 \mathrm{H}_{2} \mathrm{O}$. Refinement was started with atomic coordinates reported by Tagaki, Mathew \& Brown (1986). The four $\mathrm{H}$ atoms were refined isotropically. Full-matrix least-squares refinement was based on $F$ and the function minimized was $\Sigma w\left(\left|F_{\mathrm{o}}\right|-\left|\mathrm{F}_{\mathrm{c}}\right|\right)^{2}$, where $w(F)=1 / \sigma^{2}(F)$. The weighting scheme had a non-Poisson contribution with $p=0.050$. Corrections were made for anomalous dispersion and secondary-extinction effects $\left(g=3.6 \times 10^{-7}\right)$. During the last refinement cycle, the r.m.s. shift/e.s.d. was 0.39 . The final difference Fourier map showed no features higher than $0.78 \mathrm{e} \AA^{-3}$. In these conditions, the final $R=0.018$ and $w R=0.026$. Final atomic coordinates and equivalent isotropic temperature factors are given in Table 1.*

* Lists of structure factors and anisotropic thermal parameters have been deposited with the British Library Document Supply Centre as Supplementary Publication No. SUP 51834 (7 pp.). Copies may be obtained through The Executive Secretary, International Union of Crystallography, 5 Abbey Square, Chester CH1 $2 \mathrm{HU}$, England. 
Related literature. Little is known about cobalt phosphate hydrates. In a recent study (Cudennec, Lecerf, Riou \& Gerault, 1987), we prepared crystals of $\mathrm{Co}_{3}\left(\mathrm{PO}_{4}\right)_{2} .8 \mathrm{H}_{2} \mathrm{O}$. This solid phase belongs to the large vivianite family: $\mathrm{M}_{3}{ }_{3}\left(\mathrm{XO}_{4}\right)_{2} .8 \mathrm{H}_{2} \mathrm{O}$ with $\mathrm{M}^{\mathrm{II}}=\mathrm{Fe}, \mathrm{Co}, \mathrm{Ni}, \mathrm{Zn}, \mathrm{Mg}$ and $\mathrm{XO}_{4}=\mathrm{PO}_{4}, \mathrm{AsO}_{4}$ . The structure of vivianite: $\mathrm{Fe}_{3}\left(\mathrm{PO}_{4}\right)_{2} \cdot 8 \mathrm{H}_{2} \mathrm{O}$, was proposed by Mori \& Ito (1950), without refinement of the atomic coordinates. More recently, Hill (1979) has determined the structure of köttigite: $\mathrm{Zn}_{3}\left(\mathrm{AsO}_{4}\right)_{2} .8 \mathrm{H}_{2} \mathrm{O}$, which was refined with the $\mathrm{H}$ atoms. Lastly, Tagaki et al. (1986) have determined the structure of $\mathrm{Mg}_{3}\left(\mathrm{PO}_{4}\right)_{2} .8 \mathrm{H}_{2} \mathrm{O}$.

\section{References}

Cromer, D. T. \& Waber, J. T. (1965). Acta Cryst. 18, 104-109. Cudennec, Y., LeCerf, A., Riou, A. \& Gerault, Y. (1987). Rev. Chim. Minér. 24, $234-247$.

FrenZ, B. A. (1978). The Enraf-Nonius CAD-4 SDP - A RealTime System for Concurrent X-ray Data Collection and Crystal Structure Solution. In Computing in Crystallography, edited by H. Schenk, R. Olthof-HazeKamp, H. van Koningsveld \& G. C. BASSI, pp. 64-71. Delft Univ. Press.

HiLl, R. J. (1979). Am. Mineral. 64, 376-382.

Mori, H. \& Ito, T. (1950). Acta Cryst. 3, 1-6.

Tagaki, S., Mathew, M. \& Brown, W. E. (1986). Am. Mineral. 71, 1229-1233.

Table 1. Final atomic coordinates and equivalent isotropic temperature factors for $\mathrm{Co}_{3}\left(\mathrm{PO}_{4}\right)_{2} .8 \mathrm{H}_{2} \mathrm{O}$

\begin{tabular}{|c|c|c|c|c|}
\hline & & $=\frac{4}{3} \sum_{i} \sum_{j} \beta$ & & \\
\hline & $x$ & $y$ & $z$ & $B_{\text {eq }}\left(\AA^{2}\right)$ \\
\hline Col & 0.000 & 0.000 & 0.000 & $0.664(6)$ \\
\hline $\mathrm{Co} 2$ & 0.000 & $0 \cdot 38993$ (2) & 0.000 & $0.656(4)$ \\
\hline$P$ & $0 \cdot 31424(5)$ & 0.000 & $0 \cdot 3811(1)$ & $0.546(8)$ \\
\hline $\mathrm{O} 1$ & $0 \cdot 1573(1)$ & 0.000 & $0 \cdot 3711(3)$ & $0.84(2)$ \\
\hline $\mathrm{O} 2$ & $0 \cdot 3935(2)$ & 0.000 & $0.7092(3)$ & $0.78(2)$ \\
\hline $\mathrm{O} 3$ & $0 \cdot 3444(1)$ & $0.09648(8)$ & $0 \cdot 2282(2)$ & $0 \cdot 81(2)$ \\
\hline $\mathrm{O} 4(w)$ & $0 \cdot 4009$ (1) & $0 \cdot 38454(9)$ & $0 \cdot 1956(2)$ & $1 \cdot 07(2)$ \\
\hline $\mathrm{O} 5(w)$ & $0 \cdot 1029(1)$ & $0 \cdot 2760$ & $0 \cdot 2820$ & $1 \cdot 36(2)$ \\
\hline $\mathrm{H} 1(\mathrm{O} 4)$ & $0 \cdot 380(3)$ & $0.411(2)$ & $0 \cdot 319(6)$ & $2 \cdot 0^{*}$ \\
\hline $\mathrm{H} 2(\mathrm{O} 4)$ & $0 \cdot 348(4)$ & $0 \cdot 372(2)$ & $0 \cdot 123(6)$ & $2 \cdot 0^{*}$ \\
\hline $\mathrm{H} 3(\mathrm{O} 5)$ & $0 \cdot 116(4)$ & 0.299 (2) & $0 \cdot 382(7)$ & $2 \cdot 0^{*}$ \\
\hline $\mathrm{H} 4(\mathrm{O} 5)$ & $0.058(3)$ & $0.221(2)$ & $0.286(7)$ & $2 \cdot 0^{*}$ \\
\hline
\end{tabular}

\footnotetext{
* Atoms refined isotropically.
} 